\title{
2
}

\section{'I'm Not Expecting to Lose ...': The Election Overview and Campaign Narrative}

\author{
Marija Taflaga and John Wanna
}

\section{The countdown to a combative election}

The quotation from Malcolm Turnbull in the chapter title reflected the restrained optimism of the newly installed prime minister facing his first election as leader in the dying days of the 2016 federal election campaign. He spoke these prophetic words reluctantly when asked persistently by TV personality Annabel Crabb on her show Kitchen Cabinet about his expectations of the outcome. While Turnbull's prediction would ultimately prove accurate (only just!), Turnbull and his Coalition colleagues would get the fright of their lives when the counting began.

This chapter provides a chronology of the federal election campaign of 2016. It explores the antecedents of the main events and outcomes, and looks to provide reasons for the largely unexpected closeness of the eventual result. The chapter is broadly divided into five parts: (1) the background context and government's leadership transition along with the delicate timing and deliberate preparations for a double-dissolution election; (2) the flurry of last-minute policy announcements and budgetary measures; (3) the meandering nature of the lengthy campaign from the standpoint of the main protagonists followed by the resort to 
banal sloganeering; (4) the volatile election outcome and the descent into uncertainty; and, finally, (5) the immediate aftermath of the election and an assessment on the wisdom of calling a double dissolution.

The most noteworthy aspect of the 2016 federal election was that the election campaign really mattered. Both major contending parties went into the lengthy eight-week campaign with considerable negatives and political drawbacks (so-called 'lead in the saddlebags')—both were headed by relatively inexperienced leaders who were untested and had not previously led a national campaign; both faced mounting disaffection from their constituencies and swinging voters; and both major parties were frustrated by the dire fiscal situation with no additional money to spend unless they were prepared to allow the deficit to increase. Polling indicated that both sides would struggle to lift their primary vote back to their historical average, well into the 40 percentages. But the main battlelines of the campaign returned the contest to old-fashioned terrain-one fought over the traditional ideological contours of economic management (Liberals and Nationals) versus social provision (Labor and the Greens). Perhaps the major difference between the two sides was that the Coalition attempted to mount a bland but positive campaign focused on 'jobs and growth', whereas Labor opted for a scare campaign in the final weeks, pretending that the government had a secret plan to privatise and dismantle Medicare. At the same time, Labor emphasised health, education and jobs.

The previous federal election in September 2013 had turned out largely to be a foregone conclusion; Labor was not competitive and suffered a 'thumping defeat' while the Coalition, led by Tony Abbott, scored the second-largest majority in the parliament since 1945 (Rayner and Wanna 2015). Tactically, 'Abbott's gambit' in plumping for a strategy of outright opposition across a small number of wedge issues paid off and made the result somewhat inevitable (see Bean and McAllister 2015; Johnson and Wanna 2015). By contrast, the 2016 election was a real competitive contest and, although many commentators correctly predicted the Coalition would be returned with a reduced majority, the eventual outcome surprised many by the closeness of the result and the many closely contested seats finishing on tight margins. ${ }^{1}$

1 Arguably, the 2016 election resembled the 2010 federal election, where a first-term prime minister had just been ousted and was taunted for not being the 'real' character. The contest was close, neither major party could assemble much enthusiasm for its re-election, and the campaign largely consisted of the protagonists going through the motions. 
The Coalition was elected in 2013 on the back of a cynical campaign that whipped up a significant protest vote. Having achieved victory (becoming only the seventh opposition to win office since World War II), the new Abbott administration settled into office without a clear agenda beyond a few three-word slogans about 'stopping the boats', 'axing the (carbon) tax' and 'fixing the budget', and a vague promise to create 2 million jobs. It meant that the government found it hard to craft a positive narrative or prioritise its agenda beyond disassembling Labor's failings. Peddling the mantra that Australia was saddled with a 'budgetary crisis' of Labor's making (due to compounding annual deficits from 2008 and mounting debt levels expected to reach $\$ 470$ billion by 2018), the government attempted to take tough action in the 2014 Budget. It announced a long list of austerity measures (a scatter gun of irritants and other budgetary tightenings, rather than radical downsizing) designed to end the 'age of entitlement'. Future funding to States was reduced (by claims of up to $\$ 80$ billion from notional funding for health and education), a 2 per cent additional levy on higher income earners was imposed for three years, indexation rates for welfare payments were reduced, tougher means tests for family benefits were announced, the age at which people were entitled to the aged pension was increased to 70 , cuts to government departments were imposed and a \$7 GP copayment was proposed to help ration medical spending. The 2014 Budget was widely considered as unfair and not well received in the community. Together with other policy 'failures' such as university deregulation, the withdrawal of 'business welfare' leading to plant closures and a contentious bid to amend the Racial Discrimination Act, these incidents damaged the government's standing in the electorate. Following much protraction and bungled negotiations, many of the proposed measures were not acceptable to the Senate, leaving them as so-called 'zombie measures' haunting the government's budget bottom line.

Although the Coalition had won a comfortable victory, in government it remained deeply divided. Criticisms of Abbott's leadership grew, especially concerning his abrasive personality. A series of gaffes highlighted his errors of judgement, his polarised personal standing with the electorate and the party's consistently low polling, along with his refusal to compromise on controversial issues, and his penchant for consulting only a few handpicked advisers, such as his chief of staff Peta Credlin, exacerbated the situation (Errington and van Onselen 2015; Savva 2016). Abbott was put on notice by his party in February 2015. He survived a leadership spill 
motion 39-61, even though no challenger was prepared to contest the ballot. In a sudden opportunistic coup, the Liberals voted, in September 2015, to replace Abbott with Malcolm Turnbull, a mere 12 months before the next election was due. Abbott's party colleagues had more confidence that Turnbull could communicate effectively on economic policy and win the next election.

\section{Closer and closer to the pending abyss: Gambling on a double dissolution}

When Turnbull became PM there was a collective sigh of relief, mixed with widespread bewilderment. The Liberals, who had promised 'grownup government' and attacked Labor's disarray, infighting and leadership instability, had, by their own hands, suffered through similar leadership turmoil. But the aura surrounding the seemingly affable Turnbull's ascendancy soon diminished as his vacillating and indecisive style of leadership transcended into a sense of national disappointment. With its own conservative wing hostile to major changes, the Turnbull government, challenged by State government leaders, influential pressure groups and think tanks, soon found itself struggling to manage the policy debate in the media. ${ }^{2}$ Meanwhile, the Opposition Leader Bill Shorten, who many had underestimated or written-off as a one-note union official, suddenly rose to the occasion and began to make the dishevelled Labor caucus look electable.

Once Turnbull assumed the prime ministership, speculation about the likelihood of an early election dominated Australian politics during the initial months of 2016, especially as the government appeared to be comfortably on top in the polls and Turnbull's personal standing was high. The year 2015 ended with the Coalition 4 percentage points in front of Labor (or 52 per cent to 48 per cent in two-party preferred terms). ${ }^{3}$ Nevertheless, while Turnbull's honeymoon appeared to be holding up

2 The Turnbull government's policy difficulties arose from two sets of factors. The first set was the result of previous policy decisions undertaken by the Abbott government, as that government vacillated between arrogance and its 'born to rule mentality' and indecisiveness. The second was the product of Abbott's decision to stay on in politics, which emboldened the right faction within the Liberal Party and resulted in increased timidity and indecisiveness by the Turnbull government. 3 Used throughout this book, the term 'two-party preferred' refers to the vote for Labor and the Coalition when other parties have been excluded and have had their preferences distributed. 
into the early months of 2016, a series of political events began to fan dissatisfaction. As early as February 2016, media commentary reported that there was a 'faint air of chaos' among the executive, with Turnbull 'less in control than he might pretend'. Two stalwarts of the previous government, Warren Truss and Andrew Robb, both resigned their portfolios and indicated they would step down at the next election (Kenny 2016a). This caused a minor ministerial reshuffle, with Barnaby Joyce becoming the new Nationals leader and deputy prime minister (retaining his agricultural portfolio) and Senator Fiona Nash emerging as his deputy.

Turnbull was also unsettled by a 'forced' ministerial resignation, when it was revealed that Human Services minister Stuart Robert had gone to China to secure a trade deal between two mining companies, China Minmetals and Nimrod Resources. The latter company was headed by Paul Marks, a major Liberal party donor (Henderson 2016). After trying to rebuff Shadow Attorney-General Mark Dreyfus' attack over many days in Question Time (often with monosyllabic answers), Turnbull stood Robert down. Turnbull then asked his head of department, Martin Parkinson, to undertake an investigation into whether Robert had broken the ministerial code of conduct. Parkinson responded that Robert had not benefited financially from the activity, which was not within his portfolio responsibilities, but that he had nevertheless acted 'inconsistently' with the expected ministerial standards. Robert resigned on 12 February 2016 and was replaced by Alan Tudge (Human Services) and Dan Tehan (Defence Materiel and Veterans' Affairs). Steve Ciobo (Trade) and the Nationals' Darren Chester (Infrastructure and Transport) both joined Cabinet (Hudson 2016a).

During March, the government began to prepare the groundwork to engineer a double dissolution (the first to have occurred since 1987) over the issue of the Senate having rejected its two bills on union governance and the re-establishment of the Australian Building and Construction Commission (ABCC). The government believed that these were politically salient issues on which to fight a double-dissolution election, even though, since December 2013, it already had an earlier 'trigger' with the Clean Energy Finance Corporation (Abolition) Bill. In late March, Turnbull gave parliament an ultimatum by reintroducing the industrial relations bills for a second time. He demanded that the bills be allowed to pass or the Senate would face a double dissolution (Grattan 2016). Senators voted down the bills for a second time on 18 April-in effect sealing their fate. 
But the preparations for a double dissolution also included the government announcing its intention to reform the Senate voting system, in an attempt to reduce the influence of party preference flows that had allowed 'preference harvesting' by minor parties. Instead, the government opted to empower the voters by allowing them to allocate their own preferences, and to allow optional preferential voting so that many votes for microparties would quickly 'exhaust' and be eliminated from the voting (Borrello 2016). Following a marathon overnight sitting in the Senate with Labor and crossbench Senators filibustering against these proposed changes to the Senate voting methods (where debate largely focused on the presumed power grab by the major parties rather than on greater transparency and individual preference choices), speculation intensified that the Prime Minister would ask the Governor-General in early May to call a double-dissolution election for 2 July (the earliest possible date to avoid a subsequent half-Senate election). But he needed to prorogue the current session of parliament and immediately recall it to reconvene at an earlier date.

Accordingly, on 21 March 2016, Turnbull announced that Parliament would be brought back early (on 18 April) to give it time to consider the ABCC Fair Work (Registered Organisations) Bills a second time and also pass the necessary supply bills. He also indicated that the Budget would be brought forward by one week to Tuesday 3 May to enable it to be tabled before an election was called and to enable the Opposition Leader to deliver his Budget Reply speech (Grattan 2016). The timelines for such an electoral strategy were extraordinarily tight, with any double dissolution constitutionally needing to be called by 11 May, but with the first practical date for the election being 2 July. This strategy implied an election campaign of at least 54 days. But many seasoned observers thought that once the Senate voting reforms were passed on $21 \mathrm{March}$, the parties were already in election mode. Indeed, Labor's campaign director, George Wright, announced on the same day that: ' $\mathrm{t}$ ]he campaign starts now. We are ready'. He also predicted that the Coalition would outspend Labor by a margin of 3:1 in electioneering (Peatling 2016a).

The main motivation in contemplating a double dissolution (other than to pass the initiating legislation) was to 'clean out' the 'feral' Senate so that the government could govern and reduce the huge crossbench of 18 Senators. Many of these Senators had minuscule primary votes, but had captured positions through 'preference harvesting' and from sweetheart deals with other parties. In a double-dissolution election with 
all Senators coming up for election, many of the non-major party Senators risked losing their seats, not only the micro single-issue representatives such as Ricky Muir, Bob Day, John Madigan and David Leyonhjelm, but also the former Palmer United band of Glenn Lazarus, Jacqui Lambie and Dio Wang. Moreover, the Greens, who had supported the passage of the new Senate voting system, were vulnerable to losing a few of their 10 Senators (especially in South Australia (SA), and perhaps in Victoria and Western Australia (WA)) without the flow-on of Labor Party preferences (see further, Chapter 8). The Greens were encouraged to make their support for the electoral reforms conditional on receiving Coalition preferences in marginal inner-city seats, but seemingly did not attempt this or manage to reach agreement (Iggulden 2016a). The Coalition too faced the challenge of returning all 33 of their sitting Senators. Only Nick Xenophon really seemed to welcome a double dissolution, seeing it as a feasible way to increase his representation in the upper chamber (winning perhaps three or more full quotas outright, and possibly snaring a lower house seat) (Shepherd 2016).

Interestingly, a large proportion of members who began the 44th Parliament in September 2013 would not contest the following election for various reasons: during the term, eight parliamentarians had resigned (Kevin Rudd, Bob Carr, Kate Lundy, Brett Mason, Christine Milne, Mike Ronaldson, Penny Wright and Joe Hockey) and one had died (Don Randall). These departures were followed by an avalanche of retirements announced by serving parliamentarians indicating they would quit politics at the next election. Among government members, the Liberals' Bob Baldwin, Bruce Billson, Mal Brough, Bill Heffernan, Ian Macfarlane, Andrew Robb, Philip Ruddock, Andrew Southcott, Sharman Stone, Teresa Gambaro and eventually Bronwyn Bishop and Dennis Jensen (who both lost preselection battles) would depart parliament (although Jensen did stand as an independent candidate, and lost). The Nationals had fewer departures, although their leader Warren Truss, as well as Bruce Scott and John Cobb, chose to retire. On Labor's side, many MPs who had served in the tumultuous years under the Rudd-Gillard government, and now faced the prospect of more years in opposition, announced their retirement. Joining the three ministers (Rudd, Carr and Lundy) who had already gone were Joe Bullock, Anna Burke, John Faulkner, Laurie Ferguson, Gary Gray, Alan Griffin, Jill Hall, Joe Ludwig, Jan McLucas, Melissa Parke, Nova Peris, Bernie Ripoll, Kelvin Thomson and, surprisingly, WA's Alannah MacTiernan, who, after 
a career in State politics and just one term in Canberra, appeared reluctant to wait in the queue for a senior position in government. Then Clive Palmer announced he would not recontest once the election was called. In total, their resignations brought the departures from both chambers to some 38 members, implying a turnover of almost 17 per cent of sitting members. With Bullock retiring early, Bill Shorten was quick to nominate Aboriginal activist Pat Dodson to replace him as WA's new Labor Senator (reminiscent of Julia Gillard's 'captain's pick' of Nova Peris).

\section{Clearing the decks: A flurry of last-minute policy announcements}

On the eve of the election, the government cobbled together a number of high-visibility policy announcements to shore up its image and placate key constituencies. First, a new (but delayed) Defence White Paper (Commonwealth of Australia 2016) was released arguing for a 'rules-based global order' and reconfirming defence spending would rise to 2 per cent of gross domestic product (GDP) by 2020-21. It also committed the government to the long-term support of the 'innovative' capabilities of the Australian defence industries (Jennings 2016). Second, Malcolm Turnbull and Industry minister Christopher Pyne announced a $\$ 1$ billion Innovation and Science package just before Christmas, much of which was reannouncing previously allocated money (Hurst 2015). Then the government announced new contracts for naval ships to be built in WA, plus 12 (French-designed) submarines to be built in SA, new policies covering cyber security, funding for city planning and a funding boost for the financial regulator Australian Securities and Investment Commission (ASIC) to better police the banks (Hasham 2016; Massola 2016a; Starick 2016; Turnbull 2016). The intention to build submarines in SA was a panicky move to avoid losing marginal seats in that State. The Treasurer also announced that the sale of the vast cattle stations in the Kidman Empire to Chinese buyers would not be approved by the Foreign Investment Review Board (FIRB) on national interest grounds, appeasing considerable rural angst over the issue (Barbour, Vidot and Gunders 2016).

The government had made less progress with a number of other controversial issues. It had announced that it would implement amendments to the Competition and Consumer Act to introduce an 'effects 
test' to toughen the law so businesses could be prevented from reducing competition as a result of their actions (Barbour, Henderson and Iggulden 2016). Trade minister Steve Ciobo intended to have the Trans-Pacific Partnership (TPP) treaty ratified before parliament rose, but the legislation was left pending when parliament was suddenly prorogued (Kelly 2016). The government had also toyed with new media laws that responded to the arrival of new technologies, significant digital disruption and new players entering the field, while also allowing traditional players further aggregation. It then decided not to proceed with the legislation (Knott and White 2016). In contrast, the government did manage to repeal the act establishing the Road Safety Remuneration Tribunal (RSRT). This legislation was supposedly to promote safe driving practices, but it had in reality extended union coverage in the sector, significantly increased haulage rates for truck drivers and resulted in projections that transport costs would rise by up to 15 per cent for owner-drivers. The sudden abolition of the tribunal voided any orders it had made, a move that greatly appeased the self-employed truckies, hirers and supply-chain distributors (Hannan 2016). Meanwhile, also in April, both the Commonwealth and Queensland governments refused to intervene or offer bail-out funding to Clive Palmer's failed Queensland Nickel operations. This meant that the company was liquidated with debts of $\$ 300$ million and 550 workers were left without jobs (Elks 2015).

\section{Introducing the Budget early - framing the election with an insipid 'economic plan'}

Bringing parliament back early also meant that the 2016-17 Budget could be brought forward by one week to 3 May to allow for three days of debate before an election was called and to give Shorten the opportunity to present his speech in reply. Intending to use the Budget as a launching pad for the election, its timing was a major part of the government's strategy. Indeed, one economic commentator argued that 'for the first time ever ... we have had a budget essentially kick-off the election campaign'. He added that the election 'hasn't just become a referendum on the budget; it was deliberately chosen to be such a referendum' (McCrann 2016). Yet there was little political room to manoeuvre in a budget that was already heavily in deficit to the tune of $\$ 39.9$ billion in the current year and with a projected deficit of $\$ 37.1$ billion for the budgeted year ahead. Instead, the government was reduced to announcing a lacklustre economic 'growth 
plan'. With the prospect of an election fast approaching, both Turnbull and his Treasurer Scott Morrison struggled under the fiscal squeeze of consecutive structural deficits (now amounting to eight huge annual deficits in a row, and with no prospect of a surplus on the horizon until after 2021). They repeatedly proclaimed that 'everything was on the table' in terms of adjustments to the spending and taxing mix, and targeted health, welfare and education spending as areas for restraint. However, in relation to taxation measures, they proceeded to rule out virtually every contentious issue that came in for intense criticism. Initially, increases to the Goods and Services Tax (GST) were ruled out, mainly on political grounds (as Labor had quickly ruled out support), but also due to the likely compensation costs and because Treasury claimed an increase in GST would not augment economic growth (Anderson and Borrello 2016). Following that, changes to negative gearing were shelved, along with major cuts to income tax. The government then lowered expectations about company tax cuts (Kenny 2016b; Peatling 2016b; Tingle 2016a). The only issue that seemed to survive the melee was to put some ceiling on the tax-free superannuation balances of wealthy retirees and lower the tax concessions they received. Morrison was reduced to announcing, plaintively, that taxation as a percentage of GDP would decline from 25.9 per cent to 25.3 per cent by 2018-19 (Morrison 2016).

\section{Towards the campaign proper: Posturing politics permeates the marathon crusade}

The campaign proper got off to a lethargic start on 8 May 2016, when the Governor-General granted Turnbull's wish to hold a double dissolution and dissolved parliament. At the commencement of the eight-week campaign, the two main parties began at a measured pace rather than a canter; the Greens spent time highlighting their high-profile celebrities in key seats, while local candidates returned to their constituencies and scrambled to reactivate or build individual campaign architecture and remind voters of their beneficence. Although the main four federal parties had been engaged in 'faux campaigning' for several weeks, significant coverage in the media suggested that much of the electorate remained decidedly uninterested and were not listening (Burgess 2016; Coorey 2016b; Robertson 2016c; Young 2016). With no money to spend, the promises from the major parties ranged from the micro to the banal: funding toilet blocks and sports facilities for local communities, 
announcing minor road upgrades, offering funds for sewerage sampling to allow federal police to find 'ice labs' and commitments to improve local surveillance with the provision of additional CCTV cameras (Lee 2016). Only the Greens embarked on anything approaching a spending spree, together with proposed tax increases.

In many respects, the 2016 election campaign was a return to an older feel of Australian politics. The two major parties presented modestly contrasting economic visions, which reflected their core values, self-image and key support bases of their respective parties (also see Chapter 3). The Coalition pushed its pro-business economic credentials, promising that increased investment would promote economic growth. Labor opted to push its social agenda, advocating fairness, redistribution, along with health and education. For some, the election was uninspiring and predictable, but for those commentators with longer memories, it represented a return to traditional contours and some significant differences of priorities between the major players.

Wary of making big spending announcements, both major party leaders were regularly accused of having no new policy ideas (although various thought-bubble gimmicks were trotted out such as allowing 16- and 17-year-olds to vote) (Butler 2016). Moreover, many controversial issues such as the continuing offshore detention of 'boat people' on Manus Island and Nauru, Australian military involvement in Syria and Afghanistan or the breakdown of law and order in Aboriginal communities, such as Arukun, were off limits largely because they enjoyed bipartisan support from the major parties ${ }^{4}$ - although the Greens occasionally tried to draw attention to them (Karp 2016).

It first appeared as though Labor had opted to run a decidedly positive campaign, but the party soon departed from this script and turned heavily negative. Labor announced its ' 100 positive policies', most of which were dot-point ideas and statements of principle (Australian Labor Party (ALP) 2016a). As the party tried to defend its left flank from the Greens, it spent much of the first few weeks of the campaign denying it would enter into a coalition agreement with them after the election. Instead, it emphasised that only a majority Labor government would govern

4 Labor was initially stung by some very public internal disaffection over its acceptance of the Coalition's tough policy on unauthorised boat arrivals from candidates protesting about their party's agreement to turning boats back and continued offshore detention (Viellaris 2016). 
responsibly (Woodley 2016a). Labor's frontbench had announced plans to increase taxes on tax-evading multinationals and cut back on negative gearing so that it would apply only to new housing investments. It would increase tax on wealthy superannuants who would be expected to pay tax on pension earnings over $\$ 75,000$, and increase the renewable energy target to 50 per cent by 2030 (ALP 2016b). Significantly, the Shadow Treasurer, Chris Bowen, when launching Labor's 10-year economic plan, also admitted that the budget deficit would be greater under Labor's proposed measures than under the Coalition's plan (Tingle 2016b). This eventual admission saw Labor's campaign shift gear from being predictable and upbeat to a distinctly more negative orientation. Labor began to highlight community fears over changes to industrial relations and penalty rates. It opposed supposed cuts to school education, health and social welfare, argued against the reintroduction of the ABCC and fumed over the Coalition's plan to cut company tax over 10 years, costing some $\$ 50$ billion (see also Chapter 11).

To the disdain of many commentators (and later the Prime Minister on election night), Labor engaged in a duplicitous scare campaign over what it claimed was the Coalition's plans to sell or privatise Medicare, the so-called 'Mediscare' campaign. The 'Mediscare' blitz took off in the last three weeks of the campaign, on both social media and freeto-air advertising, playing on fears that the Coalition would wind back Medicare or shift costs on to health users. The scare campaign was contrived by disingenuous social media campaigners in Queensland's Labor headquarters, and involved former prime minister Bob Hawke fronting a television advertisement supplemented by massive cold-calling to households. Approximately 75 per cent of Labor's advertising budget was spent on negative advertising (Reece 2016).

Labor also centred its campaign around its leader and, to the surprise of many observers, Bill Shorten fought an adroit campaign sticking to his well-rehearsed scripts during daily appearances. He appeared to enjoy campaigning, and gained an energy as the weeks unfolded that allowed him to repair his abysmal approval rating, which had tanked to just 17 per cent in late 2015 (Morris 2015). As he sought to 'connect' with voters and rebuild his leadership credentials, he had to face the ignominy of speculation sourced from among his own colleagues that he would be immediately replaced after a widely expected humiliating defeat (Farr 2015). 
The Coalition, somewhat leadenly, reminded voters that its platform was essentially contained in the tabled, but yet-to-be-passed, Budget delivered to parliament in early May, seemingly under the belief that this was sufficient to deliver office in July. In a major thematic shift from the leadership of Tony Abbott, the Coalition attempted to avoid too much discussion of national security and the 'turn-back' policy on unauthorised boats, and instead focused squarely on their plans for the economy. ${ }^{5}$ With Nationals leader and Deputy Prime Minister Barnaby Joyce preoccupied in fighting off a challenge in the seat of New England against former Independent MP Tony Windsor, Turnbull's campaign team was left to focus the national campaign on the PM's ostensible affability. But, in his public performances as the spearhead campaigner, and in marked contrast to Tony Abbot in 2013, Turnbull looked flat and preoccupied throughout the campaign and never really responded to Labor's hyperbolic 'Mediscare' campaign. Suffering from influenza, Turnbull was often a little too verbose. He looked decidedly awkward in staged daily meet-and-greet events, struggled over small talk with constituents and was usually short of content and lacking any 'mongrel' in criticism of his opponents. ${ }^{6}$ In the middle of the campaign, Treasurer Scott Morrison and Finance Minister Mathias Cormann accused Labor of having a \$67 billion black hole (Iggulden 2016b). However, that same day the Treasurer was forced to retreat from his claims after sustained questioning (see further, Chapters 4 and 12).

\section{A myriad of minor campaigns and vilifying the non-establishment parties}

Significantly, the 2016 election did not simply turn into the traditional two-way fight between the main protagonists over marginal seats. Minority party support was at an all-time high, and even safe seats were vulnerable to capture from attractive opponents. Accordingly, the campaign fractured into a four-way battle for disputed territory.

5 A gaffe by Peter Dutton early in the campaign, when he said that refugees were both illiterate and likely to steal jobs, produced much acrimony among migrant communities and those with parents born overseas. Dutton's comments, however, elicited a strong defence from Julie Bishop. Both Tanya Plibersek and Sam Dastiaryi used their own personal migration stories to condemn Dutton's remarks.

6 Abbott's former chief of staff (and later media commentator during the campaign) Peta Credlin described Turnbull's performance in the campaign as 'unsure and wounded', claiming he 'didn't find the "meet and greet" easy in the campaign and it showed' (Credlin 2016). 
The predominant contest remained between the main protagonists, Coalition versus Labor, but it also included other fierce battles between 'industrial' Labor versus the 'hipster' Greens in inner-city precincts and sea-change lifestyle seats. Considerable speculation was generated over how many seats (like Melbourne, Melbourne Ports, Batman, Willis, Grayndler and Sydney) Labor would lose to Green challengers (Aston 2016b; Chang 2016a). In South Australia, the Labor-Liberal duopoly was fighting off a serious challenge from the Nick Xenophon Team, using some dirty tactics along the way, such as claiming Xenophon was a slum landlord and arranging cosy preference swaps in affected seats (Faulkner 2016). Finally, a further electoral battle was fought over Senate seats between the Coalition and various right-of-centre parties, such as Pauline Hanson's One Nation (PHON), the Liberal Democrats, Family First and other fringe parties like Derryn Hinch's Justice Party and Jacqui Lambie's Network (see Chapter 15).

Both parties amplified the creeping cartelisation in Australia's party system. They immediately urged voters to return a majority government, indicating that the spectre of another minority government or one dependent on Green support was still considered toxic among the political establishment. The third party was regularly described as 'dangerous' and 'irresponsible'. Indeed, both party leaders returned frequently to the well of minor party bashing. For instance, Turnbull declared mid-campaign that 'a vote for anyone other than my Coalition team is a vote for chaos' (Davey 2016). The Liberals frequently attacked the Greens and Labor throughout the campaign, seeking to besmirch Labor by attempting to demonstrate that they had an association with the Greens and to evoke memories of the 'Labor-Greens' alliance during the Gillard government. The Coalition hoped to tap into the fears of non-progressive voters who might regard the Greens as a radical fifth column. The Liberal Party went so far as to release a political advertisement, 'The Greening of Labor' (Liberal Party of Australia 2016). Set to abrasive rock music and using jarring editing, the advertisement attempted to portray the Greens as a sinister force dragging an already suspect Labor Party further away from the mainstream. In style, it was reminiscent of the much-mocked and ineffective 'Piracy it's a Crime' advertisements from the mid-2000s, which sought to counter the illegal copying of films and music.

Labor made similar noises, but was subtler in their critique. Shorten attacked the Greens for their opportunistic deal-making with the government to pass key legislation (on the financial disclosures of 
multinational corporations and Senate electoral reform), but maintained that Labor would nevertheless respect the crossbench and seek to work with it. Labor also ran ads attacking the Liberals for proposing to preference the Greens ahead of Labor in inner-city Melbourne seats (Hudson 2016b; Massola 2016b). In a sign of the changed times and recognition of the pressure facing the two established parties, the right-wing Daily Telegraph ran a front page declaring 'Save our Albo', and attacked the Greens candidate as an anticapitalist 'radical' (Clennell 2016). This turnaround was in stark contrast to the 2013 election, when the Daily Telegraph had depicted Albanese as the 'Nazi buffoon Sergeant Schultz' to Kevin Rudd's 'Colonel Klink' from the 1960s comedy show Hogan's Heroes-a choice that spoke volumes of the demographic profile of the newspaper's readers.

Meanwhile, the new Greens leader, Richard Di Natale, visiting numerous inner-city cafés and cheese shops, declared the Greens intent to become a party of government (also see Chapter 13). However, the party struggled to satisfy the strident demands of their own constituencies and failed to present themselves as a responsible party of government. By campaign end, the Greens were attacked for their spending promises by both major parties. Slightly off the mainstream radar, a reformulated PHON now targeting Islamisation managed to stand 15 candidates in selected lower house seats (12 in regional Queensland and three in NSW) and 16 candidates for the Senate in every State (four candidates in Queensland, three in NSW and WA and two each in the other States). While Pauline Hanson was a regular guest on commercial TV lifestyle shows, One Nation received limited coverage in the mainstream media, despite predictions from Antony Green that Hanson stood a 'realistic' chance (Iggulden 2016c). PHON's quest for the far right competed with Katter's Australian Party, the Christian Democrats, Rise Up Australia and the Citizens' Electoral League.

As the campaign progressed, Labor frequently took a narrow early lead in the polls with 51-52 per cent to 49-48 per cent in two-party preferred terms. The closeness of the polls excited predictions that Labor could win up to 12 seats from the government (six in NSW, two each in Victoria and Queensland, and one each in Tasmania and the Northern Territory), with strategists claiming a further eight seats were in doubt. There were many signs the Coalition agreed with such projections and were 'sandbagging' key marginal seats to contain their losses. 


\section{Surprises, scandals and refining campaign messages into three-word slogans}

By the middle weeks of the election, campaigning suddenly degenerated into three-word sloganeering, despite both sides promising not to stoop to such levels. For Labor, the campaign leitmotif was initially 'Putting People First', then 'Jobs, Education, Medicare', and finally honing down to the two-word slogan 'save Medicare' (despite Labor's spokeswoman for health Catherine King admitting Labor had plans to improve the Medicare transaction payment system, 'making it clear to voters that Labor would also change the information technology if it won power') (Crowe 2016). For the Coalition, their three-word response was taken from their economic plan framed in the Budget-'Jobs and Growth'-an insipid slogan repeated ad nauseam much to the annoyance of many on the Coalition backbench, who later complained to the media (Jennett 2016).

Neither Turnbull nor Shorten looked truly comfortable in drawing too heavily from the negative side of the political tactical handbook. Both leaders were happier in the realm of serious policy discussion and debate rather than the ruthless cut and thrust of political warfare. Unlike Abbott and Gillard, the style of the new leaders was not that of the battle-hardened warrior relentlessly pushing a simple message. Arguably, the removal of these former prime ministerial adversaries had the effect of lowering the intensity of political banter and hyperbole in the 2016 campaign. While Morrison tried to be more confrontational on economic management, his efforts largely backfired and he was withdrawn from the front-line campaign for many weeks. By contrast, Julie Bishop was presented as the Coalition's voice of reason. Mathias Cormann caused some mirth by mistakenly mentioning that Bill Shorten was 'very caring and very much in touch' and 'every single day promoting our national economic plan for jobs and growth' when he had intended to bolster Turnbull's credentials (Chang 2016b).

There was also plenty of typical campaign fodder besides the recourse to three-word slogans. In a sign of growing segmentation of messaging and political audiences, the Coalition's 'fake tradie' advertisement that featured a tradesman wearing a gold watch was quickly mocked across mainstream media, with Twitter generating several 'fake tradie' accounts (Koziol 2016a). Likewise, an awkward Labor advertisement in which Bill 
Shorten's wife Chloe interviewed him was dubbed bizarre by the more right-leaning media outlets, but did not garner the same level of derision online (Vickery and Burke 2016).

Even campaign tactics that seemed original were in fact reinventions of old methods. Campaign manoeuvres tended to employ new technologies to coordinate large groups of people to engage in old-style politics. Labor recruited a union-staffer army of door knockers and cold-callers who engaged in tried-and-true campaigning techniques (Park 2016). They also relied on gimmicks that aimed to elicit free media and shares on Facebook and Twitter. They also used more positive photo opportunities from Sam Dastyari's videos on multinational tax avoidance through to the 'Bill Bus' that had an entourage of frontbenchers aboard but which also kept getting stuck in driveways and easements (Dastyari 2016). Green- or Labor-aligned partisan organisations (non-party conduits such as GetUp!, affiliated Labor unions and partisan interest groups) were recruited to coordinate donations and operate phone banks and later staff the polling stations. Social media and the internet now provides activist parties with an extensive capacity to mobilise people and tap into a younger generation of 'joiners' who previously would have emerged in far smaller numbers from civil society. Only the Liberals seemed truly behind on this front, perhaps realising it was not worth the effort given their poor resource budgets and limited capacities for organisation.

The Coalition's factional difficulties emerged as a running theme from the very beginning of the campaign. Rancorous factionalism in NSW over Abbott's swift demise, and the general disorganisation of the NSW Division, saw many rank-and-file members refuse to support marginal seat holders who had been 'disloyal' to Abbott, such as Peter Hendy (Eden-Monaro) and Fiona Scott (Lindsay) (Aston 2016a; Bourke 2016; Duffy 2016; Robertson 2016a). Some former Liberals contested moderate Liberal-held seats to express their displeasure over 'traitorous behaviour'. The NSW Branch donations were also the subject of a Four Corners investigation during the campaign (McDermott, Cronau and Hoyt 2016). Peta Credlin's regular spot on Sky News gave Abbott's former chief of staff a platform from which to attack the Prime Minister. Credlin dubbed him 'Mr Harbourside Mansion' (Kenny 2016c). The situation was not helped by the media's regular focus on Abbott, though this was not always to his benefit. Footage of a lonely Abbott handing out unwanted election material at a Warringah ferry station was repeatedly recycled throughout the campaign. 
In the second half of the campaign, the Liberal Party was dogged by a political funding scandal in relation to an election software company Parakeelia, owned by the Liberal Party. Liberal parliamentarians would buy the software from the Liberal-owned company using their parliamentary allowances (Robertson 2016b; Robertson and Massola 2016). Finally, in the last weeks of the campaign, the Liberal Party was once again dogged by tensions over how the same-sex marriage plebiscite would be conducted and, should the plebiscite be successful, whether Coalition members would reserve the right to vote according to their conscience. In the days following the campaign, stories emerged that Turnbull himself had donated \$1 million to the party's financially strapped campaign (Markson 2016). He did so because of the combined problems of the NSW Electoral Commission's refusal to release public funding after the party withheld information about donation sources (Nicholls and Robertson 2016) and the revolt of its traditional base of financial supporters who closed their wallets in anger at the government's proposed superannuation changes.

Labor had its own headaches. First, there was a raid by the Australian Federal Police (AFP) on the party's Melbourne offices over leaks relating to the slow progress of the National Broadband Network (NBN). The raid sparked both controversy and embarrassment as debate raged about whether senior government figures knew about the AFP's intentions, and the fact that the police were ordered to destroy all photos as the Labor Party had claimed parliamentary privilege (Riordan and Mather 2016; Woodley 2016b). Second, the Country Fire Authority (CFA) industrial dispute in Victoria festered throughout the campaign, due to Premier Andrews insisting that union firefighters accompany volunteers at callouts and assume charge of the emergency. While many observers saw this as Victoria's new Labor government rewarding 'Labor thugs' for factional reasons, the highly public dispute sucked oxygen from federal Labor's campaign in that State. In all likelihood, the dispute cost Labor the chance to pick up Corangamite due to the low swing it received across Victoria (Morris 2016) (see Chapter 23).

\section{Leadership 'debates' and campaign launches}

A series of tepid 'leaders' debates' that occurred in the middle weeks of the campaign received only slender audience interest. Turnbull and Shorten had two highly rehearsed leaders' debates (the first held at Windsor RSL on Sky News with a minuscule pay TV audience; the second broadcast 
on free-to-air channels from the National Press Club), followed by a third held on Facebook (an Australian first) (Crowe 2016) (see also Strangio and Walter, Chapter 4, this volume). Senators Marise Payne and Stephen Conroy had a 'defence debate' that stressed the need for bipartisanship even though there were minor differences about how to deal with Chinese regional expansionism. A regional leaders' stand-off was held in late May, featuring Barnaby Joyce debating Joel Fitzgibbon and Richard Di Natale. The Deputy PM somewhat fancifully claimed that closing down the live cattle export industry to Indonesia in 2011 had resulted in a lot of [boat] people arriving in boats in Australia' (Iggulden 2016d).

In the Treasurers' debate, Morrison and Bowen debated the country's fiscal position and other economic imperatives. The event served to reinforce the return of the major parties to a traditional left-right split over major commitments between Labor and the Coalition. The Coalition promised spending and tax cuts, such as its $\$ 50$ billion corporate tax cuts over 10 years, in an attempt to promote investment-led jobs growth. Labor countered by arguing more attention needed to be paid to investments in the drivers of growth such as needs-based education and training schemes. Continuing a tradition from the last few elections, the opposition poured doubt on the government's budget costings in what proved to be a hotly contested debate that lacked a knockout blow. Throughout the campaign, Labor quietly announced its support for many of the government's budget cuts that it had previously denounced, such as on pensions and the school kids' bonus (Coorey 2016a).

Labor was the first to hold its formal campaign launch in western Sydney less than two weeks before election day (20 June), with a potpourri of Labor notables in attendance to champion Bill Shorten's return to 'Labor values'. The launch was pitched directly at the Labor base, with the campaign tacticians anxious to win back wavering Labor supporters. Drawing on Labor's legacy in providing universal health cover and celebrating Labor's past heroes Bob Hawke, Paul Keating and Julia Gillard (but not Kevin Rudd), the protection of Medicare against the Coalition's supposed plan to privatise healthcare was Shorten's centrepiece. Shorten advocated for increased spending on schools, women's equality, including more funding for domestic violence services, and he attacked the government's gay marriage plebiscite. The message was summed up by the huge banner hanging overhead 'We'll put people first', which also doubled as justification for their increased spending. What was missing was discussion of more controversial issues such as asylum seekers, 
industrial relations, the argument over the need for a federal Independent Commission Against Corruption (ICAC), foreign affairs and national security. The Coalition's official election spokesperson, Mathias Cormann, live tweeted the event and accused Shorten of merely racking up another $\$ 3$ billion on the 'spend-o-meter' (Koziol 2016b).

A week later, on 26 June, Turnbull used his campaign launch speech to the party faithful to urge Australians to 'leave nothing in doubt', and attacked the chaos of recent political instability and hung parliaments (Baxendale, Lewis and Kelly 2016). The word 'stability' was added to the Liberal's campaign slogans, and accompanying TV ads attempted to scare undecided voters about a portended Labor-Greens alliance. This message was underscored by the global reaction to the surprise 'Brexit' vote in the UK, which occurred on 23 June 2016, approximately one week out from election date. Turnbull's main message to voters was an explanation of why they should not vote against the government (rather than why they should), warning that a protest vote against the Liberals would leave the country with an uncertain future. Labor attempted to draw attention away from the Coalition's campaign launch by using spoiling tactics and releasing their own policy costings while Turnbull was speaking. However, the venture backfired when Chris Bowen had to admit that despite the savings measures that Labor had announced, Labor would have a deeper budget deficit for the next four years than would the government (Australian Broadcasting Corporation (ABC) 2016). The Greens also held their lower-key launch in Melbourne on the same afternoon.

\section{Nailbiting anxiety on election night}

Before the magnitude of Labor's scare campaign became apparent, the government and many opinion pollsters had believed a comfortable Coalition win was the most likely result. Towards the last week of the campaign, Turnbull's optimistic judgement was buttressed by a peripheral debate in the media about the significance of the unexpected Brexit vote for the incumbent government-global uncertainty was seen to underscore the theme of not swapping horses midstream. Yet other commentators cast doubt over the notion that Brexit would have a major impact. On the morning of polling day, Saturday 2 July, polling from Fairfax Media showed that the result was on a knife edge at 50-50 two-party preferred (Hartcher 2016a). 
An election that most had assumed would unfurl in a predictable manner became a nailbiter as many seats that had been considered safe for the Coalition were in doubt as counting progressed. Without the theatre of a tallyroom to observe, TV cameras had to race to individual seats (where the swings were most brutal to sitting members) or to the intended party receptions. The mood of government members appearing on TV quickly became tense as the early evening results showed a strong swing to Labor. Adding a surreal element to the evening was the gimmicky special effects graphics being shown on commercial channels. Channel Seven used its 'tower of power', with defeated MPs seated in the Speaker's chair waiting to be brutally ejected-with the tagline 'as you reject them, we'll eject them'-by being rocketed into space. Channel Nine's coverage was particularly tasteless as losing MPs were farewelled via the 'crusher', in which the smiling faces of losers were mechanically compacted into cubes for disposal and then junked.

By midnight, several Coalition MPs had conceded defeat, while other known casualties such as Wyatt Roy steadfastly refused to concede. Nick Xenophon Team's Rebekha Sharkie unseated her former boss, Jamie Briggs, by claiming victory in the former Liberal seat of Mayo (Brooks 2016). The Greens put a brave face on their disappointing evening. They had nothing much more to emphasise than the return of Melbourne MP Adam Bandt, while they held out hope of claiming Batman from Labor's inept 'faceless man' David Feeney. In both Sydney and Grayndler, where the Greens had been hoping to unseat Labor, the incumbents Tanya Plibersek and Anthony Albanese were easily returned. The Greens were further disappointed by results in Higgins, which saw the Coalition's feisty Kelly O'Dwyer returned safely; an outcome that led some tacticians to question the strategy of pulling resources out of Batman to target a safe Liberal seat. Independent sitting members Andrew Wilkie, Bob Katter and Cathy McGowan were all comfortably returned.

After six hours of counting, Bill Shorten appeared triumphant in front of a jubilant Labor crowd declaring boastfully, 'Labor is back'. Shorten gave a rousing speech, which echoed Bob Hawke and Paul Keating in emphasising Labor's strengths in managing economic reform without leaving the vulnerable exposed. Although behind in the count, Shorten looked and sounded like a winner and his speech signalled that the campaign had effectively moved into a new phase as it became clear that no result would emerge that evening. Despite his stunning result, speculation abounded about Shorten's leadership. Deputy Leader 
Tanya Plibersek kept her options open by sidestepping questions on the leadership, and rumours were reported that Anthony Albanese would mount a challenge in accordance with the ALP's new leadership ballot rules, which stipulated that the leadership be thrown open in the event of an election loss (Bramston 2016).

As the wait for Turnbull to appear intensified, speculation mounted and recriminations broke out among media personalities and Liberal politicians. Andrew Bolt denounced Turnbull for abandoning Liberal values and called for him to resign immediately. Alan Jones lashed out at fellow program guest and key Turnbull backer Senator James McGrath, calling him the 'chief bed wetter' who had panicked because of poor polls and had conspired to replace Tony Abbott as prime minister. The scene descended into acrimony, with McGrath angrily declaring Jones 'no friend of the Liberal-National party', and that Jones was 'a grub' (Koziol 2016c). Both Bolt and Jones believed that Tony Abbott would have won more seats for the Coalition, and this became the basis for several days of ugly backbiting and finger pointing within the Coalition.

When Turnbull finally appeared after 1 am on Sunday 3 July, he delivered an angry stump speech, decrying the subversion of the rule of law by militant unions and invoking the ABCC legislation that had been the trigger for Turnbull's entire strategy. Angry Liberals asked why this speech had not been given two months previously, and senior commentators panned the performance as a belated 'joke' and criticised his failure to take responsibility for the campaign outcome. Turnbull's attempts to reassure his fellow party worthies (saying the party had faced a similar situation in 1998) achieved mixed results amongst the bewildered crowd whose expectations had been shattered by the results. Compounding the uncertainty of the result on election night was the realisation that counting would not resume until Tuesday due to reforms in the wake of the bungled 2013 WA Senate election, leaving those in tight contests with anxious waits. 


\section{Descent into confused uncertainty: The prospect of a return to minority government}

The Coalition's position had worsened by Sunday morning, as seats that had been declared for the Coalition the night previously were declared undecided and classified as too close to call. In all, eight seats remained in doubt, six held by the Coalition and two by Labor. The nation had to wait for days for the count to continue as the Australian Electoral Commission (AEC) recounted existing votes and transferred uncounted ballots and postal votes around the country. The snail's pace of the count heightened the sense of uncertainty and sparked calls for electronic voting in the future.

The realisation that Australia faced the real possibility of another hung parliament inflamed tensions within the Coalition in the immediate aftermath of the electoral debacle. Conservatives attempted to link the poor result to Abbott's spectacular assassination, and Turnbull's personal authority and future as leader were openly discussed (Hartcher 2016b). Coalition MPs were universally furious at Labor's tactic of sending text messages to voters, on election day, about the Coalition's 'plan' to privatise Medicare (though Labor was later cleared by the AFP) (Lewis 2016; Moore 2016). Others, including Eric Abetz, decried the so-called underhanded tactics of GetUp! (Baines 2016), which had targeted several 'hard-right' candidates including Immigration Minister Peter Dutton, Jamie Briggs, key Abbott backer Andrew Nikolic and the controversial George Christiansen. GetUp! later claimed credit for the removal of up to eight 'hard-right' candidates, including Briggs and Nikolic (Blucher 2016; GetUp! 2016). It also claimed that others would 'never feel safe again' after the organisation amassed a large volunteer army to staff phone banks, engage in door knocking and raise funds for advertising in key seats (see Chapter 18). Cory Bernardi, also highly critical of the party's moderate leadership, announced that he would launch his own Conservative version of GetUp!. In early August 2016, he would announce that his Conservative GetUp! had collected 50,000 registrations (McIlroy 2016) and, at the beginning of 2017, Bernardi defected from the Liberal Party to go it alone in his new party, Australian Conservatives. 
Labor faced its own difficulties in the immediate post-election period. After a brief window of uncertainty over the status of Shorten's leadership, the Labor Party rallied around him, forgoing the opportunity for an anticipated spill. Labor made much of its own unity and used the public divisions within the Coalition to reinforce its campaign theme that Turnbull was ineffective because he was hostage to his right-wing factional colleagues. In the days following the poll, Shorten argued that while there was no clear winner, Turnbull was the clear loser. According to Shorten, the PM had no mandate to introduce his agenda and his 'cuts to Medicare'. Shorten continued to campaign across the country in a lap of honour and refused to concede defeat until the Coalition secured 76 seats, making the most of his opportunities to attack the government and congratulate the Labor Party on its electoral result despite a low primary vote of just 34.7 per cent.

As the Liberal Party raked through the ashes, criticisms were directed toward the party's polling capacity. In particular, they analysed the accuracy of the party's overnight tracking during the campaign, which had resulted in campaign resources being diverted from seemingly safe seats, such as Lindsay, which the party would go on to lose. Further hand-wringing occurred as party officials, including campaign Director Tony Nutt, acknowledged that they had no hope of matching Labor's capacity to organise volunteers on the ground, so much so that they had not even bothered to try (Seccombe 2016). In his post-election analysis, Tony Nutt emphasised the importance of Labor's 'Mediscare' campaign, calling it a 'cold-blooded lie' and demanding that Labor pledge to 'never again behave in that way' (Anderson 2016). Meanwhile, Labor heartily congratulated itself on turning its dire position in 2013 around within a single term.

\section{An unsure future for the government: The final result in the House}

Despite the rebuff, Turnbull quickly regrouped. When he composed himself, he claimed responsibility for the failures of the campaign, which was conducted in far too abstract terms. He also acknowledged the government's own record in the health portfolio provided 'fertile ground' for Labor's 'dishonest and misleading' campaign. He asserted that the Coalition was on track to win a slim majority in its own right and 
members of his own support base were actively talking up the government in the media. Christopher Pyne described the Liberals in sporting terms as an 'election-winning machine', with six victories from eight contests in the last 20 years (Keany 2016).

Five days after the poll, with the count continuing, Turnbull further seized the initiative by securing deals for confidence and supply with key Independents. Bob Katter declared that he supported the government with 'no enthusiasm' and stated that if Turnbull wanted to bash up unions then he would 'bash him up' and further reserved his 'right to move at any time in any other direction' (Lane 2016). A day later, on 8 July, Turnbull secured agreement from Cathy McGowan, who said, 'I asked for goodwill, I asked for regularly being in touch with each other, I asked for good governance and stability'. Andrew Wilkie also indicated that he would not vote against budget bills (Chang, Brook and Farr 2016).

Turnbull's expeditious agreements with the Independents were insurance measures. By 8 July, the election count showed the government would likely be returned with 76 or 77 seats. With the three agreements with the Independents in place, commentators declared that it was safe to say we 'have a government', even if it was not a majority government. After eight days of uncertainty, Turnbull finally declared victory on 9 July. In conceding, Shorten pledged to 'be constructive', in order to implement its program by working with the parliament, stating that Labor understood that they needed to 'to make this parliament function' (Ross and Dziedzic 2016).

In the House of Representatives, the Greens were disappointed not to win additional seats. However, they retained the seat of Melbourne and continued to build sizeable support in the safe Labor Victorian seats of Bateman and Wills. In NSW, the Greens were troubled by internal problems within that State's branch, which depressed their vote in the seats of Grayndler and Sydney, and they did not poll well in SA.

Eventually, it transpired that the Coalition lost 16 seats, but they won Chisholm from Labor and retook Fairfax after Palmer's departure, to end up with a net result of 14 . The big swings against the government were in Tasmania, NSW, SA and the Northern Territory. Labor picked up 15 seats, but lost one, with a net result of 14 seats and the biggest swings in their favour in Tasmania and WA. The Nationals ran a creditable campaign, gaining one additional seat (the Victorian Riverland seat of Murray from the Liberals), which it used to demand additional positions in cabinet. 
This request revealed the weakness of Turnbull's leadership position and forced him to expand the size of his Cabinet to 23 (the largest since the Whitlam years) in order to accommodate the Coalition partners without dropping any of his own Liberal Party colleagues.

Turnbull's hopes of winning a four-seat majority were dashed after an extended count in the knife-edge Queensland seat of Herbert, which was eventually won by Labor by a mere 37 votes. The narrowness of this victory did not elicit a Liberal-National challenge over the result in the Court of Disputed Returns. The Coalition government, thus, survived with a wafer-thin majority in the House of Representatives of two seats (76-74), which was then halved after the appointment of the Speaker, the Liberal Tony Smith. However, in reality, the government's margin was more comfortable with the support of the three conservative Independents, plus Xenophon's sitting member Rebekha Sharkie—a former Liberal staffer.

\section{After the double dissolution the real joke was on Turnbull}

The Coalition's representation in the Senate declined. It lost three Senators and managed in the double dissolution to return only 30 to the new parliament. Labor had modest success, gaining one Senator to take their numbers to 26. The Greens also went backwards, losing Robert Simms in SA for a total of nine (three of who only just scraped back in by the slimmest of margins). Rather than clearing out the Senate, Turnbull's strategy only entrenched the 'feral' crossbench further. The doubledissolution strategy was successful in ousting the former Democratic Labor Party (DLP) candidate John Madigan, Ricky Muir (Motoring Enthusiasts), Glenn Lazarus (former Palmer United Party (PUP) and Independent) and Dio Wang (PUP). However, four sitting crossbench Senators were returned: Nick Xenophon, Jacqui Lambie, Bob Day (Family First) and David Leyonhjelm (Liberal Democrats). This motley crossbench was joined by independent candidate and radio 'shock jock' Derryn Hinch from Victoria.

The main winners in the Senate were the Nick Xenophon Team, which now claimed three seats in addition to one in the lower house, and Hanson's revitalised One Nation, which claimed a total of four seats across Queensland, NSW and WA. Hence, the crossbench (comprising 
the minor parties and Independents) increased from eight to an even more unwieldy 11 (or from 18 to 20 if the Greens were included). The result left the balance of power with the Greens (should they seek to use it), with Xenophon and Hanson both empowered on the crossbench, but without sufficient numbers to hold the balance of power.

Finally, the 2016 election was also notable for several significant firsts. It was a baptism of fire for four first-time party leaders who took their parties to the poll (Malcolm Turnbull, Barnaby Joyce, Bill Shorten and Richard Di Natale). Linda Burney was the first Indigenous woman and Anne Aly the first Muslim woman to be elected to the lower house. The contest in the seat of Brisbane saw Australia's first contest between two openly gay candidates.

\section{Conclusion-orchestrated tactics that backfired}

The newly installed Turnbull government was returned, but at significant cost. The Liberal Party squandered the second-largest winning majority in the postwar era. The enormous gains made at the 2013 election were surrendered largely by the government's own making. What caused this spectacular turnaround? The Liberals opportunistically changed prime ministers in their first term back in government, replicating Labor's record of instability in government and releasing similar visceral political infighting. Abbott was never very popular as the leader of the government and, even after he was replaced, his negative image overshadowed the Turnbull government. The relief and high expectations that greeted Turnbull's initial ascension soon dissipated as he became indecisive and hostage to his phalanx of right-wingers. The Turnbull government also pursued some unpopular policy agendas that were especially controversial with the party's own supporters. Equally importantly, the Coalition managed to run an abysmally poor campaign with threadbare policies, insipid messages and a widespread perception that they had jettisoned notions of fairness.

Turnbull managed to win the barest of majorities in the House of Representatives, and after the election led a party with less capacity to manage its internal party politics. To get legislation through the Senate, the government faced an unpredictable hodgepodge of players beholden 
to ideological and populist sentiments. The composition of the Senate will likely force the government to rein in its legislative agenda. However, Labor has been inspired by their disciplined campaign achievement; a disgruntled Labor opposition has emerged more competitive as a political party, broadly united in its policy stances and internal dynamics, and with Bill Shorten's leadership cemented by the campaign in the medium term. Nonetheless, Labor's executive called for a full review of the party's election strategy in October, especially its residually low primary vote in both the House of Representatives and the Senate.

The 2016 election campaign and outcome clearly showed that Australian voters had continued their disaffection with the two major parties, and further eroded traditional party identification. The validity of Duverger's law-that two-party systems (and their electoral mechanics) discriminate against other contenders and squeeze out minor parties-appears to be questionable in the context of a disaffected electorate, a preferential voting system and a Senate list voting system. After all, at the 2016 election, the Senate combined vote for the major parties was just 65 per cent, with the Coalition receiving 35.2 per cent against Labor's vote of just 29.8 per cent. The ploy to change the Senate voting system, which was designed to cartelise the results and reduce the opportunities for minor parties to game the system, failed to halt the continuing rise of the Independents and minor parties. Obviously, the double dissolution was an important factor. While it halved the quota required to be elected, it paved the way for the Independents and minor parties to be attractive alternatives to the established combatants, who increasingly appeared to be hollowed-out, 'me-too', 'cardboard cut-outs' to many in the electorate.

\section{References}

Anderson, Fleur. 2016. 'Nutt protests Labor's "cold-blooded lie"'. Australian Financial Review, 22 September. Available at: www.afr.com/ news/politics/tony-nutt-protests-labors-coldblooded-lie-20160922grlv16

Anderson, Stephanie and Eliza Borrello. 2016. 'GST increase not being taken to election by Malcolm Turnbull'. ABC News, 16 February. Available at: www.abc.net.au/news/2016-02-16/ turnbull-rules-out-gst-change-election-policy/7172294 
Aston, Heath. 2016a. "II don't need to be a sacrificial lamb”: Mosmanbased Liberal candidate for Illawarra seats quits'. Sydney Morning Herald, 25 May. Available at: www.smh.com.au/federal-politics/ federal-election-2016/mosmanbased-liberal-candidate-for-illawarraseat-says-she-has-been-abandoned-by-party-20160525-gp35yl.html

—_. 2016b. 'Election 2016 results: Liberal Party and Greens claim Labor could lose in Melbourne Ports count'. Sydney Morning Herald, 11 July. (Original title: 'Liberal Party and Greens think shock loss looms for Labor in Melbourne Ports). Available at: www.smh.com.au/ federal-politics/federal-election-2016/election-2016-results-liberalparty-and-greens-claim-labor-could-lose-in-melbourne-ports-count20160710-gq2ue0.html

Australian Broadcasting Corporation (ABC). 2016. 'As it happened: Labor unveils costings, Malcolm Turnbull officially launches Coalition campaign'. $A B C$ News, 26 June. Available at: www.abc.net.au/ news/2016-06-26/election-live-june-26/7544386

Australian Labor Party (ALP). 2016a. 'Labor's 100 Positive Policies'. Originally available at: www.100 positivepolicies.org.au/ (site discontinued).

—_. 2016b. '10 Year plan for Australia's economy'. 7 July. Originally available at: www.100positivepolicies.org.au/laborseconomicplan (site discontinued).

Baines, Richard. 2016. 'Election 2016: Liberal Party needs to be more savvy against GetUp, Abetz says'. ABC News, 5 July. (Original title: 'Abetz says Liberal must be more "savvy" to "expose dishonest" GetUp'). Available at: www.abc.net.au/news/2016-07-05/election-2016-liberaleric-abetz-party-needs-to-be-more-savvy/7568858

Barbour, Lucy, Anna Henderson and Tom Iggulden. 2016. 'Cabinet strikes agreement on effects test changes, big businesses "disappointed" by move'. ABC News, 16 March. (Original title: 'Government's move to introduce "effects test" angers big business'). Available at: www. abc.net.au/news/2016-03-16/government-effects-test-angers-bigbusiness/7251192 
Barbour, Lucy, Anna Vidot and Jodie Gunders. 2016. 'Scott Morrison knocks back sale of S. Kidman \& Co due to "national interest". ABC News, 29 April. Available at: www.abc.net.au/news/2016-0429/sale-of-s.-kidman-\&-co-'contrary-to-national-interest':-morrison/ 7370926

Baxendale, Rachel, Rosie Lewis and Joe Kelly. 2016. 'Federal election live: Malcolm Turnbull launches election campaign'. Australian, 26 June. Available at: www.theaustralian.com.au/national-affairs/ federal-election-live-malcolm-turnbull-launches-election-campaign/ news-story/285e1b4df9cca675382477940bb5aa5d

Bean, Clive and Ian McAllister. 2015. 'Documenting the Inevitable: Voting behaviour at the 2013 Australian election'. In Johnson, Carol and John Wanna with Hsu-Ann Lee (eds), Abbott's Gambit: The 2013 Australian Federal Election. Canberra: ANU Press, pp. 41124. doi.org/10.22459/AG.01.2015.24

Blucher, Alex. 2016. 'Finger-pointing begins over Liberal losses in Tasmania'. $A B C$ News, 4 July. Available at: www.abc.net.au/ news/2016-07-04/election-2016-finger-pointing-begins-liberallosses-tasmania/7565690

Borrello, Eliza. 2016. 'Senate reform: Electoral laws passed after marathon Parliament sitting'. ABC News, 18 March. Available at: www.abc.net. $\mathrm{au} /$ news/2016-03-18/senate-electoral-reform-laws-passed/7258212

Bourke, Latika. 2016. 'Leaked email suggests some Liberals want Peter Hendy to lose bellwether seat'. Sydney Morning Herald, 9 May. (Original title: 'Leaked email suggests Liberal divisions over Peter Hendy's Eden-Monaro seat'). Available at: www.smh.com.au/politics/ federal/leaked-email-suggests-some-liberals-want-peter-hendy-tolose-his-bellwether-seat-20160510-goqanx.html

Bramston, Troy. 2016. 'Bill Shorten goes from federal election to Labor leadership contest'. Australian, 2 July. (Original title: 'Heat's on for Shorten'). Available at: www.theaustralian.com.au/opinion/columnists/ troy-bramston/bill-shorten-goes-from-federal-election-to-laborleadership-contest/news-story/e0c3fcf1ece4b38784bb7725de6e41b6 
Brooks, Emily. 2016. 'NXT Candidate Rebekha Sharkie wins Mayo, knocks off Briggs'. Huffington Post, 2 July. Available at: www. huffingtonpost.com.au/2016/07/02/nxt-candidate-rebekha-sharkiewins-mayo-knocks-off-briggs/

Burgess, Katie. 2016. 'Why young people aren't enrolling to vote for 2016 federal election'. Sydney Morning Herald, 15 May. Available at: www.smh.com.au/federal-politics/federal-election-2016/why-youngpeople-arent-enrolling-to-vote-for-2016-federal-election-20160510goqmf5.html

Butler, Josh. 2016. 'Labor wants a Senate inquiry into lowering voting age to 16'. Huffington Post, 27 June. Available at: www.huffingtonpost. com.au/2016/06/26/labor-wants-a-senate-inquiry-into-loweringvoting-age-to- $16 /$

Chang, Charis. 2016a. "The Greens could be "quite powerful" in next parliament'. news.com.au, 12 May. Available at: www.news.com.au/ national/federal-election/the-greens-could-be-quite-powerful-in-nextparliament/news-story/d2c95f8eb948279c40f74074017d9639

2016b. 'Mathias Cormann accidentally endorses Bill Shorten as "very caring"'. news.com.au, 25 May. Available at: www.news.com. $\mathrm{au} /$ national/federal-election/mathias-cormann-accidentally-endorsesbill-shorten-as-very-caring/news-story/2b1f7104111fdf579035 e437ec369406

Chang, Charis, Benedict Brook and Malcolm Farr. 2016. 'Coalition inches closer to Government'. news.com.au, 7 July. (Original title: 'The Coalition are inching closer to an outright majority'). Available at: www.news.com.au/national/federal-election/federal-election-results2016-coalition-inches-closer-to-government/news-story/124636eb 946dcadb6ad6c82aae696a9c

Clennell, Andrew. 2016. 'Save our Albo'. Daily Telegraph, 11 May, p. 1.

Commonwealth of Australia. 2016. 2016 Defence White Paper. Canberra, ACT: Department of Defence. www.defence.gov.au/WhitePaper/

Coorey, Phillip. 2016a. 'Election 2016: Labor backs down on budget cuts as pressure grows'. Australian Financial Review, 9 June. Available at: www.afr.com/news/politics/election-2016-labor-backs-down-onbudget-cuts-as-pressure-grows-20160608-gpew6g 
2016b. 'Election 2016: Bored, cynical swing voters proving impossible to engage'. Australian Financial Review, 14 June. Available at: www.afr.com/news/politics/election-2016-voters-arebored-and-cynical-20160613-gpibez

Credlin, Peta. 2016. 'Time for Turnbull to get IHS mojo working'. Australian, 12 September, p. 23.

Crowe, David. 2016. 'ALP Medicare hypocrisy attacked'. Australian, 20 June. Available at: www.theaustralian.com.au/link/9132568 e10287f8312300a8703b03002?domain=theaustralian.com.au

Dastyari, Sam. 2016. 'Labor's Sam Dastyari and kids star in "cutest guide to tax avoidance" - video'. Guardian, 12 May. Available at: www. theguardian.com/australia-news/video/2016/may/12/labors-samdastyari-and-kids-star-in-cutest-guide-to-tax-avoidance-video

Davey, Melissa. 2016. 'Election 2016: Turnbull urges voters to avoid "chaos of a hung parliament". Guardian, 4 June. Available at: www.theguardian.com/australia-news/2016/jun/04/election-2016turnbull-urges-voters-to-avoid-chaos-of-a-hung-parliament

Duffy, Connor. 2016. 'MP Fiona Scott accused of stabbing Tony Abbott in the back'. $A B C$ News, 9 May. Available at: www.abc.net.au/7.30/ content/2015/s4458944.htm

Elks, Sarah. 2015. 'Queensland Nickel: Treasurer refuses Clive Palmer bailout request'. Australian, 13 December. Available at: www. theaustralian.com.au/link/84b008177c7e423ca5fa13b66aee65cb? domain=theaustralian.. com.au

Errington, Wayne and Peter van Onselen. 2015. Battleground: Why the Liberal Party Shirtfronted Tony Abbott. Melbourne: Melbourne University Publishing.

Farr, Malcolm. 2015. 'Opposition Leader nominates Budget as showdown time with Malcolm Turnbull and vows not to give up'. news.com.au, 24 November. Available at: www.news.com.au/finance/work/leaders/ opposition-leader-nominates-budget-as-showdown-time-withmalcolm-turnbull-and-vows-not-to-give-up/news-story/86a $86 a 8580$ de1010efc3aa8ee4a803bf 
Faulkner, Dean. 2016. 'Election 2016: Nick Xenophon Team "unpredictable", "crackpots", Labor's Tanya Plibersek says'. $A B C$ News, 15 June. (Original title: 'Labor calls Nick Xenophon team "unpredictable", "crackpots"). Available at: www.abc.net. au/news/2016-06-15/election-2016-tanya-plibersek-calls-nickxenophon-team-crackpots/7511356

Getup!. 2016. 'GetUp! Lauds its election campaign; Liberals disagree'. AustralianPolitics.com, 9 July. Available at: www.australianpolitics. com/2016/07/09/getup-lauds-its-election-campaign.html

Grattan, Michelle. 2016. 'Turnbull ultimatum: July 2 double dissolution unless reconvened Senate passes industrial relations bills'. The Conversation, 21 March. Available at: www.theconversation.com/ turnbull-ultimatum-july-2-double-dissolution-unless-reconvenedsenate-passes-industrial-relations-bills-56586

Hannan, Erwin. 2016. 'Senate votes to scrap road safety tribunal'. Australian Financial Review, 19 April. Available at: www.afr.com/ news/senate-votes-to-scrap-road-safety-tribunal-20160418-go9g46

Hartcher, Peter. 2016a. 'Federal election 2016: It's 50-50, so what was the point of it all?' Sydney Morning Herald, 1 July. Available at: www.smh. com.au/federal-politics/federal-election-2016/federal-election-2016its-5050-so-what-was-the-point-of-it-all-20160630-gpvuzj.html

__ 2016b. 'Election result reveals both parties have lost themselves in all-consuming narcissism'. The Sydney Morning Herald, 3 July. Available at: www.smh.com.au/federal-politics/federal-election-2016/ election-result-reveals-both-parties-have-lost-themselves-in-anallconsuming-narcissism-20160703-gpxbd3.html

Hasham, Nicole. 2016. 'Turnbull government's plan to make cities cooler and greener'. Sydney Morning Herald, 18 January. Available at: www. smh.com.au/federal-politics/political-news/turnbull-governmentsplan-to-make-cities-cooler-and-greener-20160118-gm8fdz.html

Henderson, Anna. 2016. 'Stuart Robert resigns from Turnbull ministry following probe into China trip'. $A B C$ News, 12 February. Available at: www.abc.net.au/news/2016-02-12/stuart-robert-to-resignfom-ministry-abc-understands/7163226 
Hudson, Phillip. 2016a. 'Turnbull cabinet goes into election year short of experience'. Weekend Australian, 15 February. (Original title: 'Cabinet's leap into the unknown'). Available at: www.theaustralian. com.au/link/9a2b5987eb7450ed 981bad3cf02e74fc? domain= theaustralian.com.au

- 2016b. 'Federal election 2016: Labor ads to target Libs-Greens deals' . Weekend Australian, 23 May. Available at: www.theaustralian.com.au/ link/d5e5e89d051 cefef5ff388031371558b?domain=theaustralian. com.au

Hurst, Daniel. 2015. 'Malcolm Turnbull's innovation package offers tax breaks and school focus'. Guardian, 7 December. Available at: www. theguardian.com/australia-news $/ 2015 / \mathrm{dec} / 07 / \mathrm{malcolm}$-turnbullinnovation-package-tax-breaks-school-focus

Iggulden, Tom. 2016a. 'Greens under fire over Senate reform and Liberal preference deal'. $A B C$ News, 12 March. Available at: www.abc.net.au/ $\mathrm{am} /$ content/2016/s4423761.htm

—. 2016b. 'Major parties do battle over budget black holes'. ABC Radio, 24 May. Available at: www.abc.net.au/pm/content/2016/ s4467727.htm

- 2016c. 'Election 2016: Pauline Hanson a realistic chance of returning to Canberra, Antony Green says'. $A B C$ News, 24 May. Available at: www.abc.net.au/news/2016-05-24/pauline-hanson-arealistic-chance-of-returning-to-canberra/7440944

- 2016d. 'PM contradicts his deputy on asylum seeker link with cattle ban'. ABC News, 26 May. Available at: www.abc.net.au/worldtoday/ content/2016/s4469671.htm?site=sydney

Jennett, Greg. 2016. 'Election 2016: Coalition's “jobs and growth" campaign criticised by surviving MPs '. $A B C$ News, 18 July. (Original title: 'Coalition strategists defend "jobs and growth" campaign criticism'). Available at: www.abc.net.au/news/2016-07-18/coalition'sjobs-and-growth-campaign-criticised/7638588

Jennings, Peter. 2016. 'The 2016 Defence White Paper: Good posture'. The Strategist, 25 February. Available at: www.aspistrategist.org.au/the2016-defence-white-paper-good-posture/ 
Johnson, Carol and John Wanna. 2015. 'Conclusion: Reflections on Abbott's Gambit-Mantras, manipulation and mandates'. In Carol Johnson and John Wanna with Hsu-Ann Lee (eds), Abbott's Gambit: The 2013 Australian Federal Election. Canberra: ANU Press, pp. 425-36. doi.org/10.22459/AG.01.2015.25

Karp, Paul. 2016. 'Greens would demand asylum seeker policy change under any deal with Labor'. Guardian, 15 May. Available at: www. theguardian.com/australia-news/2016/may/15/greens-would-demand -change-to-asylum-seeker-policy-under-power-sharing-deal-withlabor

Keany, Francis. 2016. 'Election 2016: Christopher Pyne declares Coalition victory, as PM meets with another crossbench MP'. $A B C$ News, 8 July. Available at: www.abc.net.au/news/2016-07-08/election2016-christopher-pyne-declares-coalition-victory/7579634

Kelly, Joe. 2016. 'Ciobo pushes to legislate TPP'. Australian, 14 March. Available at: www.theaustralian.com.au/national-affairs/ foreign-affairs/ciobo-pushes-to-legislate-tpp/news-story/ed30dca 7aa75b629249e223df6561832

Kenny, Mark. 2016a. 'Ministerial exodus unbalances Malcolm Turnbull's team'. Sydney Morning Herald, 11 February. (Original title: 'Five ministers in four months: Exodus unbalances Turnbull team'). Available at: www.smh.com.au/federal-politics/political-news/ ministerial-exodus-unbalances-malcolm-turnbulls-team-20160210gmqoqj.html

- 2016b. 'Federal budget 2016: Coalition shifts on income tax to tackle bracket creep'. The Sydney Morning Herald, 26 April. Available at: www. smh.com.au/business/federal-budget/federal-budget-2016-coalitionshifts-on-income-tax-to-tackle-bracket-creep-20160426-gofg4e.html

_- 2016c. 'Peta Credlin questions campaign tactics of "Mr Harbourside Mansion” Malcolm Turnbull'. Age, 13 May. Available at: www.theage. com.au/federal-politics/federal-election-2016/peta-credlin-questionscampaign-tactics-of-mr-harbourside-mansion-malcolm-turnbull20160512-gotu72.html 
Knott, Matthew and Dominic White. 2016. 'Media reform: Turnbull cabinet approves new laws, paving way for mergers and acquisitions'. Sydney Morning Herald, 23 February. Available at: www.smh.com. au/federal-politics/political-news/media-reform-turnbull-cabinetapproves-new-laws-paving-way-for-mergers-and-acquisitions-2016 0222-gn0t56.html

Koziol, Michael. 2016a. 'Federal election 2016: Labor's campaign launch'. Sydney Morning Herald, 19 June. Available at: www.smh.com.au/ federal-politics/federal-election-2016/federal-election-2016-laborscampaign-launch-20160619-gpmjao.html

— 2016b. 'Federal election 2016: "Fake tradie" commercial ridiculed as latest campaign ads fall flat'. Sydney Morning Herald, 21 June. Available at: www.smh.com.au/federal-politics/federal-election-2016/ federal-election-2016-fake-tradie-commercial-ridiculed-as-latestcampaign-ads-fall-flat-20160620-gpn3bu.html

—. 2016c. 'Election 2016: "You are actually a grub": Alan Jones in on-air barney with Malcolm Turnbull backer'. Sydney Morning Herald, 2 July. Available at: www.smh.com.au/federal-politics/federalelection-2016/election-2016-you-are-actually-a-grub-alan-jones-inonair-barney-with-malcolm-turnbull-backer-20160702-gpx60e.html

Lane, Sabra. 2016. 'Election count continues as Coalition secures supply and confidence deal with Bob Katter'. 7.30, $A B C$, 7 July. Available at: www.abc.net.au/7.30/content/2016/s4496680.htm

Lee, Jane. 2016. 'Federal election: Labor pledges to outspend Coalition on local roads, transport, sport centres'. Sydney Morning Herald, 19 June. Available at: www.smh.com.au/federal-politics/federal-election-2016/ federal-election-labor-pledges-to-outspend-coalition-on-local-roadstransport-sport-centres-20160618-gpmc75.html

Lewis, Rosie. 2016. 'AFP clears ALP over Medicare texts'. Australian, 2 August. Available at: www.theaustralian.com.au/federal-election-2016/ afp-clears-labor-over-medicare-text-messages/news-story/bc630df009c 903 fce $96 \mathrm{e} 03 \mathrm{ae} 74832 \mathrm{~d} 6 \mathrm{~b}$

Liberal Party of Australia. 2016. 'The Greening of Labor'. YouTube, 14 June. Available at: www.youtube.com/watch?v=eA4Me7X5Blw 
Markson, Sharri. 2016. 'PM's \$1m bailout for Liberals'. Australian, 14 July. Available at: www.theaustralian.com.au/federal-election2016/federal-election-2016-turnbulls-1-million-for-liberals/newsstory/e772ee3b25359482bb17669213643951

Massola, James. 2016a. 'ASIC boost: Big companies to pay $\$ 330 \mathrm{~m}$ a year to fund regulator'. Sydney Morning Herald, 20 April. Available at: www. smh.com.au/federal-politics/political-news/asic-boost-big-companiesto-pay-more-than-330m-a-year-to-fund-regulator-20160420-gob2dv. html

. 2016b. 'Election 2016: Greens' dummy spit over preferences as unedifying as it is hypocritical'. Sydney Morning Herald, 12 June. (Original title: 'Preference fallout: Richard Di Natale's dummy spit as unedifying as it was hypocritical'). Available at: www.smh.com.au/ federal-politics/federal-election-2016-opinion/election-2016-greensdummy-spit-over-preferences-as-unedifying-as-it-is-hypocritical20160612-gphaqu.html

McCrann, Terry. 2016. 'Federal Budget 2016: Super tax hit seemed good idea at the time'. Australian, 14 May. Available at: www. theaustralian.com.au/link/e8e2dc0bf4c499e6193eda554c2c7fae? domain=theaustralian.com.au

McDermott, Quentin, Peter Cronau and Shaun Hoyt. 2016. 'Money and Influence'. ABC Four Corners, 24 May. Available at: www.abc.net. $\mathrm{au} / 4$ corners/stories/2016/05/23/4465448.htm

McIlroy, Tom. 2016. 'Cory Bernardi's Australian Conservatives group signs up 50,000 people online'. Sydney Morning Herald, 2 August. Available at: www.smh.com.au/federal-politics/political-news/corybernardis-australian-conservatives-group-signs-up-50000-peopleonline-20160801-gqin07.html

Moore, Tony. 2016. 'Federal election 2016: Shorten confirms Labor sent "Mediscare" text'. Sydney Morning Herald, 6 July. Available at: www.smh.com.au/federal-politics/federal-election-2016/federalelection-2016-shorten-confirms-labor-sent-mediscare-text-2016 0705-gpzasl.html 
Morris, Madeleine. 2016. 'Election 2016: Victorian CFA dispute could claim federal Labor scalps'. $A B C$ News, 23 June. Available at: www. abc.net.au/news/2016-06-22/bitter-cfa-dispute-could-claim-federallabor-scalps/7533338

Morris, Sophie. 2015. 'Bill Shorten's life with a 17 per cent approval rating'. Saturday Paper, 7-13 November. Available at: www.thesaturday paper.com.au/news/politics/2015/11/07/bill-shortens-life-with-17cent-approval-rating/14468148002600

Morrison, Scott. 2016. 'Interview with Peter van Onselen \& Paul Kelly, Sky News Australian Agenda'. Transcript: 24 January. Available at: www.sjm.ministers.treasury.gov.au/transcript/007-2016/

Nicholls, Sean and James Robertson. 2016. 'NSW Liberals "concealed" illegal donors before 2011 election win'. Sydney Morning Herald, 23 March. Available at: www.smh.com.au/nsw/nsw-liberals-concealedillegal-donors-before-2011-election-win-20160323-gnpsn6.html

Park, Andy. 2016. 'Inside a 21st century election campaign: How big data and social media are being used to target your vote'. ABC News, 7 May. (Original title: 'How social media will be this election's critical battleground'). Available at: www.abc.net.au/news/2016-0506/social-media-battle-pivotal-in-campaign/7391576

Peatling, Stephanie. 2016a. 'Election 2016: Malcolm Turnbull names a date'. Sydney Morning Herald, 22 March. Available at: www.smh. com.au/federal-politics/political-news/election-2016-malcolmturnbull-names-a-date-20160320-gnmyig.html

— 2016b. 'Malcolm Turnbull takes negative gearing changes off the table'. Sydney Morning Herald, 24 April. Available at: www.smh.com. au/business/federal-budget/budget-2016-malcolm-turnbull-takesnegative-gearing-changes-off-the-table-20160423-godovg.html

Rayner, Jennifer and John Wanna. 2015. 'An Overview of the 2013 Federal Election Campaign: Ruinous politics, cynical adversarialism and contending agendas'. In Johnson, Carol and John Wanna with HsuAnn Lee (eds), Abbott's Gambit: The 2013 Australian Federal Election. Canberra: ANU Press, pp. 17-34. doi.org/10.22459/AG.01.2015.01 
Reece, Nick. 2016. 'Why scare campaigns like "Mediscare" work - even if voters hate them'. The Conversation, 14 July. Available at: www.the conversation.com/why-scare-campaigns-like-mediscare-work-even-ifvoters-hate-them-62279

Riordan, Primrose and Joanna Mather. 2016. 'Labor offices raided by AFP'. Australian Financial Review, 19 May. Available at: www.afr.com/ news/politics/election/labor-offices-raided-by-afp-20160519-gozcoi

Robertson, James. 2016a. 'Election 2016: Half of the government's 20 most vulnerable seats are in NSW'. Sydney Morning Herald, 8 May. Available at: www.smh.com.au/federal-politics/federal-election-2016/ election-2016-half-of-the-governments-20-most-vulnerable-seats-arein-nsw-20160506-goo1i9.html

__. 2016b. 'Election 2016: MPs giving taxpayer funds to Liberal Partylinked company and donor'. Sydney Morning Herald, 8 June. Available at: www.smh.com.au/federal-politics/federal-election-2016/election2016-mps-directing-taxpayer-funds-towards-liberal-partylinkedcompany-and-donor-20160608-gpe87q.html

__. 2016c. 'How to swing a Sydney voter in a boring election'. Sydney Morning Herald, 1 July. Available at: www.smh.com.au/ comment/how-to-swing-a-sydney-voter-in-a-boring-election-2016 0630-gpv7g6.html

Robertson, James and James Massola. 2016. 'Election 2016: Government staff worked for Liberal software company Parakeelia'. Sydney Morning Herald, 13 June. (Original title: "It looks like a scam": Software company and government staff linked'). Available at: www.smh.com. $\mathrm{au} /$ federal-politics/federal-election-2016/government-staffers-providedfree-training-for-liberal-software-donor-20160612-gphdz9.html

Ross, Monique and Stephen Dziedzic. 2016. 'Election 2016: Malcolm Turnbull claims victory after Bill Shorten concedes defeat'. $A B C$ News, 10 July. (Original title: “It's vital this parliament works": Turnbull claims election win'). Available at: www.abc.net.au/news/2016-07-10/ election-2016-malcolm-turnbull-claims-election-victory/7584400

Savva, Niki. 2016. The Road to Ruin: How Tony Abbott and Peta Credlin Destroyed their own Government. Melbourne: Scribe Publications. 
Seccombe, Mike. 2016. 'How GetUp! boosted Labor in Election 2016'. Saturday Paper, 9-15 July. Available at: www.thesaturdaypaper. com.au/news/politics/2016/07/09/how-getup-boosted-laborelection-2016/14679864003471

Shepherd, Tory. 2016. 'Senate reform could boost Nick Xenophon, kill off minor parties'. Adelaide Advertiser, 22 February. Available at: www.adelaidenow.com.au/news/south-australia/senate-reform-couldboost-nick-xenophon-kill-off-minor-parties/news-story/0d9d44c77f3 01498ef250eb767d2b4b0

Starick, Paul. 2016. '\$50bn Future Submarines to be built at Osborne in Adelaide by French firm DCNS'. Adelaide Advertiser, 26 April. Available at: www.adelaidenow.com.au/news/south-australia/pmmalcolm-turnbull-on-50bn-future-submarines-project/news-story/ be2a8da55f6066ba070454d667729c04

Tingle, Laura. 2016a. 'Turnbull government scales back tax cut ambitions'. Australian Financial Review, 10 April. Available at: www. afr.com/news/policy/budget/turnbull-government-scales-back-taxcutambitions-20160410-go2waz

_. 2016b. 'Election 2016: Labor's make-or-break week of rebuilding of economic credibility'. Australian Financial Review, 9 June. Available at: www.afr.com/opinion/columnists/laura-tingle/election-2016-laborsmakeorbreak-week-of-rebuilding-of-economic-credibility-2016 0609-gpezyw

Turnbull, Malcolm. 2016. 'Australia's Cyber Security Strategy'. Media release: 21 April. Department of Prime Minister and Cabinet. Available at: www.malcolmturnbull.com.au/media/launchof-australias-cyber-security-strategy

Vickery, Kara and Liz Burke. 2016. 'Bill Shorten's bizarre interview with wife Chloe Shorten'. news.com.au, 19 June. Available at: www. news.com.au/national/federal-election/federal-election-2016-chloeshortens-peculiar-interview-with-husband-bill-shorten/news-story/ fea0e9c0755a2ee54d4600283d62132b 
Viellaris, Renee. 2016. 'Federal election 2016: Headache for Shorten as trio jump ship'. Courier-Mail, 18 May. Available at: www.couriermail.com. $\mathrm{au} / \mathrm{news} / \mathrm{national} /$ federal-election/federal-election-2016-headachefor-shorten-as-trio-jump-ship/news-story/4ec1d9826db8afa0b6824 f8dd202d103

Woodley, Naomi. 2016a. 'Liberals and Labor rule out governing coalition with the Greens'. $A B C$ News, 11 May. Available at: www.abc.net.au/ $\mathrm{pm} /$ content/2016/s4460129.htm

__ 2016b. 'Labor to pursue questions over photos of NBN documents in AFP search'. ABC News, 21 May. Available at: www.abc.net.au/am/ content/2016/s4466662.htm

Young, Matt. 2016. 'What happens if you don't vote this Federal Election?' news.com.au, 2 July. Available at: www.news.com.au/national/federalelection/what-happens-if-you-dont-vote-this-federal-election/news-st ory/13ec72bd81bed56329066d6253b31317 
This text is taken from Double Disillusion: The 2016 Australian Federal Election, edited by Anika Gauja, Peter Chen, Jennifer Curtin and Juliet Pietsch, published 2018 by ANU Press, The Australian

National University, Canberra, Australia.

doi.org/10.22459/DD.04.2018.02 